\title{
RETROSPECTIVE ANALYSIS OF LEPTOSPIROSIS MORBIDITY IN IVANO-FRANKIVSK REGION (EPIDEMIOLOGICAL AND CLINICAL CHARACTERISTICS)
}

DOl: 10.36740/WLek202007117

\author{
Oleksandra Ya. Pryshliak, Tetiana 0. Nikiforova, Zoriana R. Tylishchak, Oleksandr P. Boichuk, Nadiya V. Vaskul, \\ Oksana V. Kopchak, Andriy L. Protsyk \\ IVANO-FRANKIVSK NATIONAL MEDICAL UNIVERSITY, IVANO-FRANKIVSK, UKRAINE
}

\begin{abstract}
The aim: To perform a retrospective analysis of leptospirosis morbidity in Ivano-Frankivsk region, to give the etiological characteristics of leptospirosis according to clinicallaboratory parameters, to determine the peculiarities of the course, prognostic features.

Materials and methods: Data of the State Enterprise "Ivano-Frankivsk Regional Laboratory Center of the Ministry of Health of Ukraine", reports and abstracts of medical records of the Regional Clinical Infectious Diseases Hospital for 2009-2018 were used. Clinical observation of patients, analysis of general-clinical, biochemical, and serological indices were carried out.

Results: The leptospirosis morbidity in Ivano-Frankivsk region during 2009-2018 was higher than in general in Ukraine. Activation of foci of leptospirosis L. pomona and grippotyphosa in 2009-2013, decrease of L. grippotyphosa and increase of L. pomona foci and “new” L. autumnalis, australis, bataviae, cynopteri in 2014-2018 were noted. The emergence of leptospirosis L. autumnalis, which had a high virulence and caused a severe course, was noted.

Conclusions: The leptospirosis morbidity in the Ivano-Frankivsk region over the past 10 years has exceeded the incidence in Ukraine and varied within 0.62-2.2 per 100,000. During the last 5 years, the serological structure has changed: L. pomona (27.7\%) prevailed, L. grippotyphosa decreased (2.1\%), L. bataviae and cynopteri, autumnalis increased (by 8.5\%). Seasonality is shifted in the autumn-winter period (November-February) (L. grippotyphosa, australis, pomona, canicola). According to forecasts, leptospirosis induced by L. autumnalis was most adverse. Leptospiroses of serogroups L. australis, bataviae, cynopteri had a mild course, there were fewer complications.
\end{abstract}

KEY WORDS: Leptospirosis, seasonality, focus, serogroup, Ivano-Frankivsk region

Wiad Lek. 2020;73(7):1397-1401

\section{INTRODUCTION}

The pandemic distribution of leptospirosis causes considerable attention to this disease. The disease is registered more than in 80 countries of the world and ranks third in terms of natural-focal diseases $[1,2,3]$. A lot of attention has been paid to the study of leptospirosis in Ukraine: epidemiology has been studied in different geographical areas, natural foci have been identified, and the link between morbidity and the farming system, clinical manifestations, treatment methods [4, 5] have been determined. The difficult economic situation in Ukraine led to the destruction of the system of sanitary-veterinary control of the population of rodents - the main sources of leptospirosis pathogens. Also, the etiological structure of morbidity, periodicity and seasonality has significantly changed [6]. Due to the severity of the clinical course and indicators of lethality, leptospirosis is one of the first places in infectious pathology. The mortality rate of the disease in Ukraine in recent years is about $10 \%$. High mortality is associated with the toxic effect of the pathogen on the important organs of the human being (kidney, liver, heart) $[3,7,8,9]$.

Leptospirosis is the most widespread in the Western and Central regions of Ukraine, and the highest level is registered in the Lviv, Ivano-Frankivsk, Ternopil and Rivne regions. The peculiarity of the Ivano-Frankivsk region is determined by its physical-geographical location, favorable weather conditions and composition of the fauna, which provides the prerequisites for the formation of the natural and anthropurgic foci of leptospirosis $[5,10]$. Earlier in Ukraine and in the region the Leptospira of serovar L. icterohaemorrhagiae dominated, but from 2010 the leading place was occupied by Leptospira L. grippotyphosa, L. pomona, L. canicola and L. hebdomadis $[5,11]$. It is believed that diseases caused by Leptospira of different serogroups have a single pathogenesis and pathological anatomy, clinical course, but this situation is not entirely accurate $[12,13]$. Studies performed by us during 2009-2013 show the activation of the cells of L. pomona leptospirosis, as well as the occurrence of sporadic cases of $\mathrm{L}$. autumnalis leptospirosis, which was characterized by high virulence and severity of the course of the disease. Some cases of leptospirosis of serogroups L. australis and L. bataviae had a mild course [14]. Taking into account the high morbidity, lethality of leptospirosis, the diversity of serovariants of pathogens, the emergence of new foci, more careful study of regional peculiarities of the epidemiological trend and clinical manifestations of this disease. 


\section{THE AIM}

To perform a retrospective analysis of the morbidity of leptospirosis in the Ivano-Frankivsk region, to give the etiological characteristics of leptospirosis according to clinical-laboratory parameters, to determine the peculiarities of the course, prognostic signs.

\section{MATERIALS AND METHODS}

There were used data of the State Enterprise "Ivano-Frankivsk Regional Laboratory Center of the Ministry of Health of Ukraine", reports of the Regional Clinical Infectious Diseases Hospital (RCIDH), hospitalization records of patients treated in RCIDH for the period from 2009 to 2018 inclusive. The clinical observation of patients, analysis of general-clinical and biochemical parameters, serological results of the examination were performed.

\section{RESULTS AND DISCUSSION}

The Ivano-Frankivsk region is located in the west of Ukraine and borders on Lviv, Ternopil, Chernivtsi and Zakarpatska. In the south it has a state border with Romania, where there is also high leptospirosis morbidity. By the nature of the relief, the region is divided into three parts: plain, foothill, and mountainous. The flat part - area near the river Dniester - is adjacent to the Dniester River. Here the forest-steppe dominates - the agricultural area of the region. In the middle part - the foothills - the forest landscape with broad-leaved forests prevails. The mountainous part of the region is occupied by the Eastern Carpathians. The region is in the zone of moderately continental climate, the most humid in Ukraine (humidity coefficient is 1.5-3.0). The average annual precipitation - is from 600 to $1550 \mathrm{~mm}$. Water resources are represented by superficial (rivers, lakes, reservoirs) and underground waters. There are three water reservoirs in the region (Burshtyn, Chechva, Kniahynyn) with an area of 1670 hectares. The rivers with a length of up to $10 \mathrm{~km}-8128$, over $10 \mathrm{~km}-188$, and over $100 \mathrm{~km}$ - four, prevail: Dniester $(1362 \mathrm{~km})$, Prut $(910 \mathrm{~km})$, Limnytsa $(122 \mathrm{~km})$, Svicha $(107 \mathrm{~km})$. The prevalence of the population occupied by agricultural labor and geographical peculiarities contribute to the spread of pathogens of leptospirosis among rodents, animals and human infection.

The morbidity of leptospirosis in Ivano-Frankivsk oblast and in Ukraine over the last 10 years (2009-2018) is represented in Table I.

From the data in Table I, it is evident that the leptospirosis morbidity in the Ivano-Frankivsk region was higher than in the whole Ukraine in all years except 2012. The high rates were in 2010, 2014 and 2018 (2.71,2.27, 2.26 per 100 thousand of population respectively).

Retrospective data on the incidence of leptospirosis in the region from 1980 to 2018 are represented in Figure 1.

Retrospectively, in the dynamics of morbidity in leptospirosis, three periods can be distinguished: from 1980 to 1988 - during some years the disease has not been registered or there have been sporadic cases. Since 1988, the rise in the morbidity with a maximum in $1992-7.56$ per 100 thousand of population, and a gradual decrease before $2000-2.34$ per 100 thousand of population. Since then, the intensive index varies within the 3.48-0.62 per 100 thousand. Fluctuations indicate a certain periodicity of the increase in leptospirosis morbidity (3 years), which is related to the level of infection of domestic and agricultural animals, the number of rodents, the sanitary condition of settlements, the volume of deratization.

Territorial distribution of leptospirosis morbidity in the region has its own peculiarities. Primarily, the incidence was recorded the area near the Dniester river: Halych (2011 - 4.54 per 100 thousand), Kolomyia (2010 - 6.59 per 100 thousand), Dolyna (2012 - 2.92 per 100 thousand), Tysmenytsia (2013 - 2.32 per 100 thousand) areas. Gradually, the morbidity spread to the foothills where a dense river network is developed. In mountainous regions (Verkhovyna, Nadvirna), very rare cases were registered. The number of foci increases, there were added Tlumach (2016 - 4.12, 2018 - 6.29 per 100 thousand), Snyatyn (2016 - 3.15, 2018 - 10.76 per 100 thousand), Horodenka districts (2016 - 3.83, 2018 - 4.11 per 100 thousand). Over the past 5 years, mortality in the region was an average 0.32 per 100 thousand, in Ukraine -0.12 per 100 thousand of population.

There is a clear summer-autumn seasonality of leptospirosis - from July to October. On average, the increase in morbidity begins to be recorded from July each year (9.2\% from average annual) with a clear peak in September (24.6\% from average annual) and October (10.8\% from average annual). Seasonality is due to agricultural activity in summer (June-July) and harvesting in autumn (September), as well as infection through water. The second peak of morbidity is observed in December (12.3\%), coincides with the migration of mouse rodents from the environment into the outbuildings.

In RCIH over the past 10 years, 161 patients with leptospirosis were treated ( $85.7 \%$ of the diagnosis was confirmed serologically), 11 persons died (mortality rate $-6.8 \%$ ). To evaluate changes in the etiological spectrum, patient charts for 2009-2013 and 2014-2018 were analyzed.

The basis of the etiological spectrum in the first group (63 serologically confirmed cases) were: L. pomona (22.92\%) and L. grippotyphosa (22.92\%), L. icterohaemorrhagiae (16.6\%), L. canicola - $10.42 \%$, there were new Leptospira which were not previously registered: L. autumnalis (10.42\%), L. australis (6.28\%), L. bataviae (6.28\%), L. cynopteri $(4.16 \%)$.

In 2014-2018 (75 serologically confirmed cases), in the etiological composition of leptospirosis there was a shift. L. pomona also prevailed - $27.7 \%$, but L. grippotyphosa decreased to $2.1 \%$, L. icterohaemorrhagiae and L. canicola were often met (by 12.8\%), L. bataviae and L. cynopteri L autumnalis (by 8.5\%) were registered more often, there were single cases of L. tarassovi and L. australis (by 2.1\%). In part of patients in 2018 (15.9\% of all), 2-3 Leptospira were detected in diagnostic titters (1:200-1:800). Among them the "new" Leptospira prevailed that were not pre- 


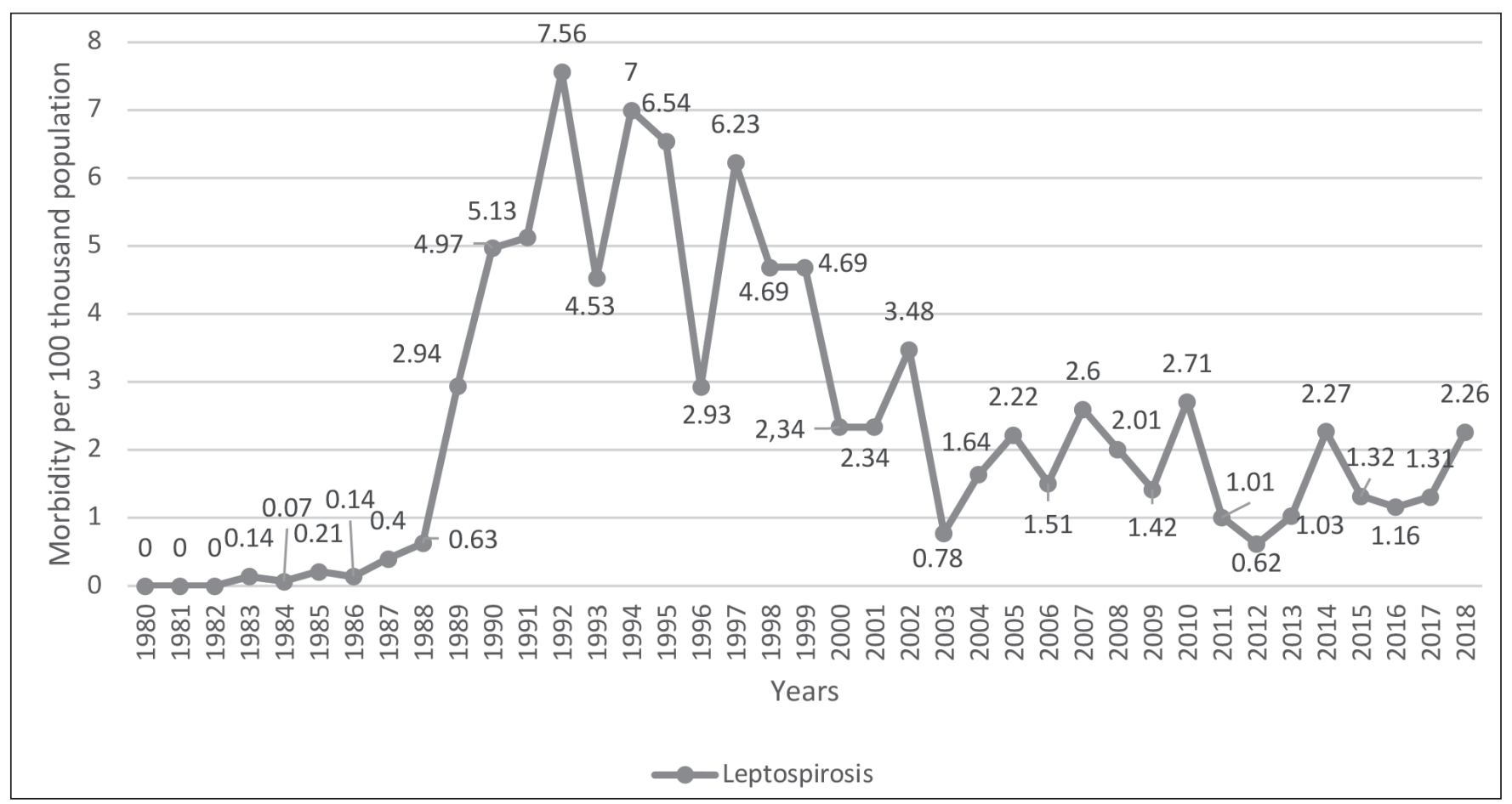

Fig. 1. Leptospirosis morbidity in Ivano-Frankivsk region for the period of 1980-2018 (per 100 thousand population)

Table I. Leptospirosis morbidity in Ivano-Frankivsk region and Ukraine for the period of 2009-2018 (per 100 thousand population).

\begin{tabular}{cccccc}
\hline Years & \multicolumn{2}{c}{ Ivano-Frankivsk region } & \multicolumn{2}{c}{ Ukraine } & $\begin{array}{c}\text { Relative indicator of } \\
\text { the comparison of the } \\
\text { intensity index }\end{array}$ \\
\hline 2009 & 20 & 1.42 & 438 & 0.95 & 1.50 \\
\hline 2010 & 38 & 2.71 & 632 & 1.37 & 1.98 \\
\hline 2011 & 15 & 1.01 & 314 & 0.68 & 1.49 \\
\hline 2012 & 9 & 0.62 & 316 & 0.7 & -0.89 \\
\hline 2013 & 14 & 1.03 & 320 & 0.79 & 1.30 \\
\hline 2014 & 31 & 2.27 & 474 & 1.04 & 2.18 \\
\hline 2015 & 18 & 1.32 & 301 & 0.7 & 1.89 \\
\hline 2016 & 16 & 1.16 & 321 & 0.76 & 1.53 \\
\hline 2017 & 18 & 1.31 & 322 & 0.78 & 1.68 \\
\hline 2018 & 31 & 2.26 & 273 & 0.64 & 3.53 \\
\hline
\end{tabular}

viously found - L. javanica, or were rarely registered - L. bataviae, L. cynopteri, L. autumnalis, often in conjunction with L. icterohaemorrhagiae. Of all the fatal cases in 2018, one is due to a combination of 3 serovariants: L. icterohaemorrhagiae, L. grippotyphosa and L. pomona.

The patient charts (epidemiological history, clinical manifestations and laboratory data) were analyzed for the comparison of diseases caused by different serogroups. Men dominated $-77.1 \%$, rural population, aged from 22 to 82 , the largest group included individuals aged 50-70. Children were two under 18 years of age, with leptospirosis L. rhomona, of moderate severity. There were no mild forms, medium severe $-10.4 \%$ (L. pomona, cynopteri), anicteric - $4.3 \%$ (L. grippotyphosa, pomona, australis). The rest of the patients were diagnosed with a severe form.
The water route predominated in summer in patients with L. pomona, bataviae, grippotyphosa: patients drank dirty water, swam in the river, the pond. In other cases, the infection was associated with the care of animals and the contact with rodents. Patients were admitted to RCIH from June to October, but few cases - in the inter-season period in April-May (L. grippotyphosa, icterohaemorrhagiae) and in the autumn-winter period (November-February) (L. grippotyphosa, australis, pomona, canicola). It's interesting, that L. autumnalis corresponded to its name and was registered only in September-October.

Most patients had a high temperature $-39-40^{\circ} \mathrm{C}$; it was somewhat lower in patients with L. australis $-37.5-39^{\circ} \mathrm{C}$. All patients had pain in the muscles, except for a few patients with L. australis, pomona. Nausea and vomiting 
were noted in $21 \%$ of patients, most often with L. grippotyphosa and canicola. All patients had jaundice, except for single anicteric forms. High average values of bilirubin were in patients with L. icterohaemorrhagiae, autumnalis, canicola, - 397.08 $\pm 25.20,485.89 \pm 41.22,372.50 \pm 30.09$ $\mu \mathrm{mol} / \mathrm{l}$, respectively. The protein spectrum (total protein and albumins) changed most in L. grippotyphosa and autumnalis (decreased to $45 \mathrm{~g} / \mathrm{l}$ and $40 \%$, respectively). The least damage to the liver was in patients with $\mathrm{L}$. australis and cynopteri (bilirubin - 108.36 $\pm 9.90,143.85 \pm 12.45$ $\mu \mathrm{mol} / \mathrm{l})$. The largest size of the liver was in patients with L. autumnalis $(17.5 \pm 0.8 \mathrm{~cm})$, and the smallest one was in L. canicola, grippotyphosa $(14.3 \pm 0.1 \mathrm{~cm})$. Anemia, leukocytosis, high ESR were in all patients, but L. grippotyphosa (leukocytosis $-26.0 \pm 1.8^{\star} 10^{9}$ ), L. icterohaemorrhagiae $(\mathrm{Hb}-88 \pm 6.2 \mathrm{~g} / \mathrm{l}), \mathrm{L}$. autumnalis (ESR $-57.0 \pm 4.2 \mathrm{~mm} / \mathrm{h}$ ) gave the greatest shifts in average hematological indices. In patients with L. pomona, L. cynopteri, L. bataviae, these indices changed to a much lesser extent.

Acute renal failure (ARF) with polyuria phenomena was present in almost all patients. The most severe ARF was caused by L. icterohaemorrhagiae (urea $-26.10 \pm 3.83$ $\mathrm{mmol} / \mathrm{l}$ ), L. grippotyphosa (creatinine $-375.79 \pm 28.32$ $\mathrm{mmol} / \mathrm{l}$ ), and also L. autumnalis, canicola. Significantly lower were those in patients with L. cynopteri and australis (urea $-17.98 \pm 0$, creatinine $-173.55 \pm 10.32$, urea - 19.08 \pm 1.67 , creatinine $-277.90 \pm 18.92 \mathrm{mmol} / \mathrm{l}$, respectively). Acute hepatic encephalopathy (precoma 1) and DIC syndrome were observed in 1 patient with $\mathrm{L}$. autumnalis and in 1 patient with L. grippotyphosa. Infectious-toxic shock of the 1-2 degree was in 2 patients with L. icterohaemorrhagiae and in 1 patient with L. canicola. Hemorrhagic syndrome was most pronounced and more frequent in L. grippotyphosa, icterohaemorrhagiae, autumnalis. Reactive pancreatitis was observed in $76 \%$ of patients with different Leptospira, with the exception of L. cynopteri, australis, and was accompanied by an increase in the level of $\dot{\alpha}$-amylase of blood, diastase of urine, hyperglycemia. Pneumonia was found in $34.8 \%$ of patients with different serovariants, complicated by pleurisy, hydrothorax, respiratory insufficiency. Cardiac damage (carditis, atrial fibrillation) was observed in leptospiroses L. icterohaemorrhagiae, grippotyphosa, autumnalis, pomona. Unfortunately, L. javanica was registered only in combination with other Leptospira, that did not give us the possibility to reveal its clinical peculiarities.

Thus, in Ivano-Frankivsk oblast, the intensification of the foci of the leptospirosis of the serogroup L. rhomona and grippotyphosa in 2009-2013, the sharp reduction of L. grippotyphosa in 2014-2018 and the increase of the foci of L. rhomona and the "new" Leptospira L. autumnalis, australis, bataviae, cynopter, javanica. The emergence of new foci of leptospirosis in foothill areas is explained by an increase in the number of infected rodents, mammals, domestic animals due to the infection of soil, water, unsatisfactory vaccination of domestic animals, the termination of both urban and field 2-time deratization. According to the clinical and laboratory features, one can distinguish etiologic differences in leptospiroses, the occurrence of leptospirosis cases in the serogroup of L. autumnalis, which has high virulence, with the severity of the disease is not inferior to the traditional serogroups - L. grippotyphosa and L. icterohaemorrhagiae. Single cases of leptospirosis of serogroups L. cynopteri and L. australis have a mild course. These data require further investigation in terms of evidence.

\section{CONCLUSIONS}

1. The morbidity of leptospirosis in the Ivano-Frankivsk region over the past 10 years has exceeded the level of morbidity in Ukraine and ranged from 0.62 to 2.2 per 100 thousand of population.

2. During the last 5 years the serological structure of leptospiroses in the Ivano-Frankivsk oblast has changed. The leading role in epidemiology was L. rhomona (27.7\%). The topicality of L. grippotyphosa (2.1\%) has decreased, the registration of L. bataviae and L. cynopteri, L. autumnalis (by $8.5 \%$ ) has increased.

3. Periodicity of rise in leptospirosis morbidity was determined every 3 years. Seasonality is shifted in the autumn-winter period (November-February) (L. grippotyphosa, L. australis, L. pomona, L. canicola).

4. Prognostic most adverse is the course of leptospirosis caused by L. autumnalis. Leptospiroses of the serogroups L. australis, L. bataviae, L. cynopteri had a relatively easier course and much less complications.

\section{REFERENCES}

1. Vasylieva N.A., Andreichyn M.A. Leptospiroz: monohrafiia [Leptospirosis: monograph]. Ternopil: Ternopilskyi derzhavnyi medychnyi universytet. $2016 ; 276$.

2. Allan K.J., Biggs H.M., Halliday J.E. et al. Epidemiology of Leptospirosis in Africa: A Systematic Review of a Neglected Zoonosis and a Paradigm for 'One Health' in Africa. PLoS Negl. Trop. Dis. 2015;14(9):223-229.

3. Haake D.A., Levett P.N. Leptospirosis in humans. Curr. Top. Microbiol. Immunol. 2015; 387:65-97.

4. Dykyi B.M., Pryshliak 0.Y., Kiriiak 0.P. et al. Leptospiroz: aktualnist, epidemiolohiia [Leptospirosis: topicality, epidemiology]. Galician Medical Journal. 2005; 2(1):72-73. (In Ukrainian).

5. Pryshliak 0.Y., Piuryk V.F., Dykyi B.M. et al. Kliniko-epidemiolohichna kharakterystyka leptospirozu v Ivano-Frankivskii oblasti [Clinical and epidemiological characteristics of leptospirosis in Ivano-Frankivsk region]. Materialy Vseukrainskoi naukovo-praktychnoi konferentsii ta plenumu Asotsiatsii infektsionistiv Sumshchyny "Infektsiini khvoroby v praktytsi likaria-internista: suchasni aspekty"; May 2015; Sumy, Ukraina; 2015:97-100. (In Ukrainian).

6. Zubach 0., Telegina T., Semenyshyn 0. et al. Leptospirosis in Ukraine (Lviv Oblast): Clinical and Epidemiological Features. Vector Borne Zoonotic Dis. 2019; 19(5):341-346.

7. Boonpucknavig V., Douangchawee G., Niwattaykul K. Infectious Diseases and Tropical Disease Pathology: SY16-2A Pathology of leptospirosis: autopsy study. Pathology. 2014; 46(2):27.

8. Zubach E., Zinchuk A. Kliniko-epidemiologicheskaya harakteristika letalnyih sluchaev leptospiroza vo Lvovskom regione [Clinical and epidemiological characteristics of lethal cases of leptospirosis in the Lviv region]. Clinical infectology and parasitology. 2018;7(2):173-179. 
9. Goswami R.P., Goswami R.P., Basu A. et al. Predictors of mortality in leptospirosis: an observational study from two hospitals in Kolkata, eastern India. Trans. R. Soc. Trop. Med. Hyg. 2014; 108(12):791-796.

10. Zubach E.A., Telehyna T.V., Semenyshyn O.B. Epyzootolohycheskaia kharakterystyka leptospyroza y osobennosty zarazhenyia liudei vo Lvovskom rehyone [Epizootologic characteristics of leptospirosis and the peculiarities of infection of people in the Lviv region]. Klinicheskaya infektologiya i parazitologiya. 2017; 6(3):314-322. (In Ukrainian).

11. Andrushak M.0. Kliniko-epidemiolohichna kharakterystyka zakhvoriuvan na leptospiroz za 2014-2018 rr. na Bukovyni [Clinicalepidemiological characteristics of the leptospirosis morbidity during 2014-2018 in Bukovyna]. Aktualnaya infektologiya. 2019;7(2): 19-20. (In Ukrainian).

12. Vasylieva N.A., KravchukYu.A. Leptospiroz, sprychynenyi kombinatsiieiu zbudnykiv, u Ternopilskii oblasti [Leptospirosis caused by a combination of pathogens in the Ternopil region]. Infektsiini khvoroby. 2015;2:48-52. (In Ukrainian).

13. Chidambaram N., Ramanathan M., Anandi V. et al. Leptospirosis: clinical presentation and correlation with serovars. J. Commun. Dis. 2007; 39(2):105-108.

14. Nikiforova T.0., Kopchak O.V., Buderkevych L.I. et al. Porivnialna kharakterystyka leptospirozu, sprychynenoho riznymy serohrupamy leptospir [Comparative characteristics of leptospirosis caused by different serotypes of Leptospira]. Materialy Vseukrainskoi naukovopraktychnoi konferentsii infektsionistiv «Pryrodno-oseredkovi infektsii»; 17-18.05.2012, Uzhhorod, Ukraina. Ternopil: TDMU, Ukrmedknyha; 2012:70-72. (In Ukrainian).

The scientific study was performed within the framework of the scientific-research work of the Department of Infectious Diseases and Epidemiology of the Ivano-Frankivsk National Medical University (Ukraine) "The course of infectious diseases against the background of concomitant pathology, combined chronic infections and invasions, treatment correction", state registration number $0119 U 100571$.

\section{ORCID and contributionship:}

Oleksandra Ya. Pryshliak: 0000-0002-3256-5108 ${ }^{F}$

Tatiana O. Nikiforova: 0000-0002-5891-0168 ${ }^{D}$

Zoriana R. Tylishchak: 0000-0002-7891-2849 ${ }^{B}$

Oleksandr P. Boichuk: 0000-0003-0646-6533 A

Nadiya V. Vaskul: 0000-0002-5368-7948 ${ }^{\mathrm{E}}$

Oksana V. Kopchak: 0000-0002-6352-6638 ${ }^{\mathrm{C}}$

Andrii L. Protsyk: 0000-0003-2041-5337 ${ }^{B}$

\section{Conflict of interest:}

The Authors declare no conflict of interest.

\section{CORRESPONDING AUTHOR Oleksandr P. Boichuk \\ Ivano-Frankivsk National Medical University \\ 2 Galitska st., 76000 Ivano-Frankivsk, Ukraine \\ tel: +380506749109 \\ e-mail: opboy@ukr.net}

Received: 11.10 .2019

Accepted: 17.04 .2020

\footnotetext{
A - Work concept and design, B - Data collection and analysis, C - Responsibility for statistical analysis, D - Writing the article, $\mathbf{E}$ - Critical review, $\mathbf{F}$ - Final approval of the article
} 